\title{
The stroke-prone spontaneously hypertensive rat: still a useful model for post-GWAS genetic studies?
}

\author{
Toru Nabika ${ }^{1}$, Hiroki Ohara ${ }^{1}$, Norihiro Kato ${ }^{2}$ and Minoru Isomura ${ }^{1}$ \\ The stroke-prone spontaneously hypertensive rat (SHRSP) is a unique genetic model of severe hypertension and cerebral stroke. \\ SHRSP, as well as the spontaneously hypertensive rat, the parental strain of SHRSP, has made a tremendous contribution to \\ cardiovascular research. However, the genetic mechanisms underlying hypertension and stroke in these rats have not yet been \\ clarified. Recent studies using whole-genome sequencing and comprehensive gene expression analyses combined with classical \\ quantitative trait loci analyses provided several candidate genes, such as Ephx2, Gstm1 and SIc34a1, which still need further \\ evidence to define their pathological roles. Currently, genome-wide association studies can directly identify candidate genes for \\ hypertension in the human genome. Thus, genetic studies in SHRSP and other rat models must be focused on the pathogenetic \\ roles of 'networks of interacting genes' in hypertension, instead of searching for individual candidate genes. \\ Hypertension Research (2012) 35, 477-484; doi:10.1038/hr.2012.30; published online 8 March 2012
}

Keywords: cerebral stroke; genetics; hypertension; QTL; SHRSP

\section{INTRODUCTION}

The stroke-prone spontaneously hypertensive rat (SHRSP) is a unique genetic model of severe hypertension and cerebral stroke. Two decades have passed since the first pioneering studies on quantitative trait loci (QTLs) of blood pressure (BP) in SHRSP. ${ }^{1,2}$ In spite of all efforts, the genetic mechanisms underlying hypertension or cerebral stroke in this rat model remain unknown. During this period, genetic analyses in humans have progressed dramatically. Technologies have made it possible to genotype a large number of samples and analyze an enormous amount of single-nucleotide polymorphism data. Genome-wide association studies (GWAS) that rely on such advanced technologies have revealed a number of loci associated with increased BP in humans. ${ }^{3-10}$

Under such circumstance, what is the role of SHRSP and other models in genetic studies of cardiovascular diseases? In this review, we will address this issue and summarize the genetic studies performed thus far in SHRSP.

\section{ESTABLISHMENT OF SHRSP}

SHRSP was established from a substrain of spontaneously hypertensive rats (SHR; substrain A in Figure 1a) in 1974 by Okamoto et al. ${ }^{11}$ SHRSP was created under the following circumstances: (1) the selection was started using 24th generation SHR, (2) a high stroke susceptibility was fixed only after three generations of selection and (3) severe hypertension was simultaneously fixed with the stroke susceptibility. ${ }^{11}$ The established strain had a high incidence of stroke (80 vs. $10 \%)$ and severe hypertension (220-240 vs. $180-200 \mathrm{~mm} \mathrm{Hg}$ ) when compared with SHR. ${ }^{11}$
Although it is unknown whether strict inbreeding was applied in the initial breeding process of SHR, the genetic pool was expected to be small at the 24th generation. According to the National BioResource Project for the Rat database (http://www.anim.med. kyoto-u.ac.jp/nbr/default.aspx), ${ }^{12}$ which collected genotypes of 357 simple sequence length polymorphism markers in 179 inbred rat strains, 7 substrains of SHR (CH, CL, B2 and Izm) and SHRSP (A1-sb, A3 and Izm), which were originally developed at Kyoto University (Figure 1a), shared 1 or 2 alleles at each of the 332 markers (93\%). A total of 3 or 4 alleles were found at the other 25 simple sequence length polymorphisms among those 7 substrains. Considering the simple sequence length polymorphism markers were polymorphic enough to have 5 to 19 (or more) alleles among the 179 strains, we think it reasonable to assume the majority of the genome of SHR and SHRSP has been derived from a pair of 'ancestral' rats.

In contrast, it is important to note that the larger strain difference in the genome that does not contribute to hypertension is observed between WKY and SHR/SHRSP. This finding is principally because WKY was established independently from another pair of 'ancestral' rats in the same closed colony (Figure 1a).

SHR, SHRSP and WKY were distributed to several laboratories before they were established as fully inbred strains (Figure 1b). This process of distribution has introduced another source of variations in genetic make-up among these strains, which imposes additional difficulties when performing genetic analyses in SHR/SHRSP (see the discussion below).

\footnotetext{
${ }^{1}$ Department of Functional Pathology, Shimane University School of Medicine, Izumo, Japan and 2Department of Gene Diagnostics and Therapeutics, Research Institute, National Center for Global Health and Medicine, Tokyo, Japan

Correspondence: Dr T Nabika, Department of Functional Pathology, Shimane University School of Medicine, Izumo 693-8501, Japan.

E-mail: nabika@med.shimane-u.ac.jp
}

Received 24 November 2011; revised 8 January 2012; accepted 11 January 2012; published online 8 March 2012 


\section{GENETIC STUDIES ON HYPERTENSION AND CEREBRAL STROKE IN SHRSP}

After the seminal works published in 1991,1,2 many QTLs for BP have been identified in SHR/SHRSP. Because of their polygenic nature, the chromosomal regions responsible for hypertension varied among pairs of hypertensive and normotensive rat strains used in QTL analyses. In fact, the Rat Genome Database (http://rgd.mcw.edu/) has compiled more than 300 QTLs influencing BP in rats, ${ }^{13}$ and a substantial part of these QTLs were identified in experimental crosses between SHR/ SHRSP and normotensive rat strains. In spite of many QTLs being identified, few causative genes have been identified thus far. In the following sections, several recent genetic studies on hypertension and stroke in SHRSP are reviewed.
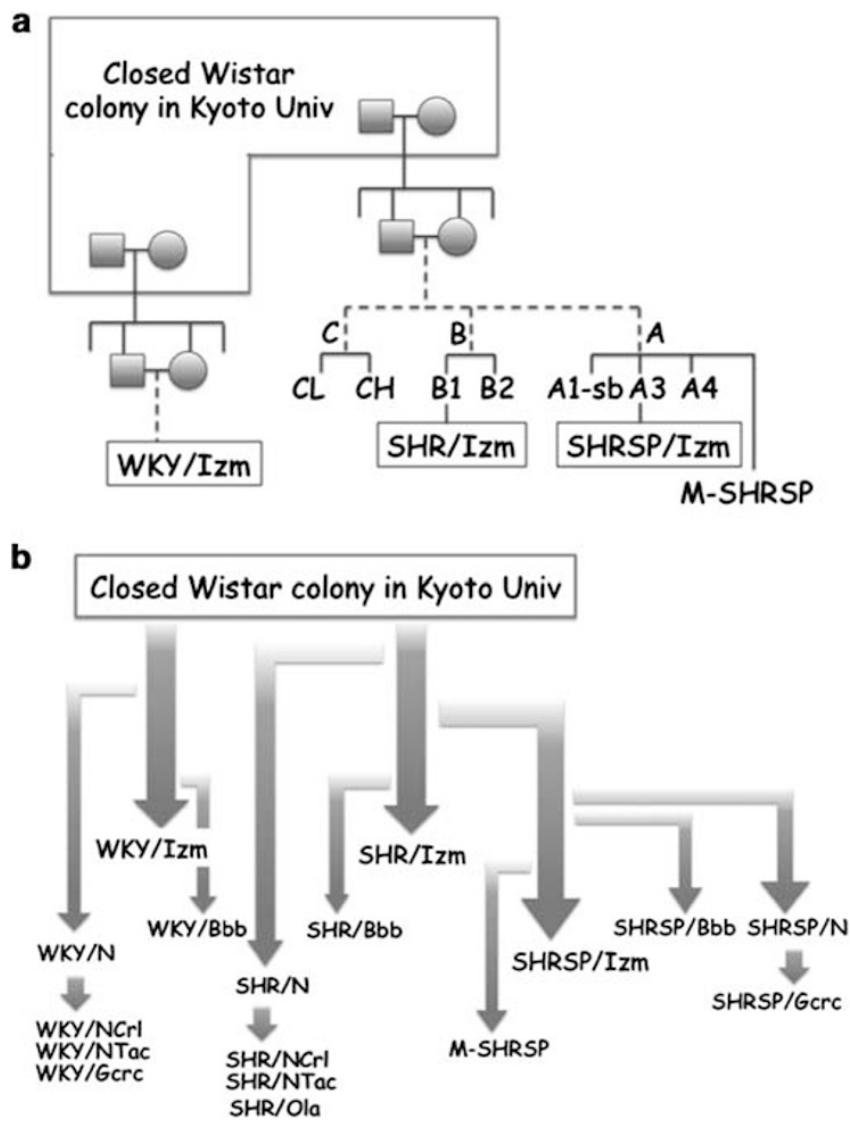

Figure 1 Origins of the SHRSP, SHR and WKY substrains. (a) The original substrains established by Okamoto and his colleagues. (b) The substrains currently used in the world.
Candidate genes detected by QTL analysis

Soluble epoxide hydrolase (Ephx2). Soluble epoxide hydrolase (sEH), encoded by the Ephx2 gene, is an enzyme that metabolizes epoxyeicosatrienoic acids. Because epoxyeicosatrienoic acids act as vasodilators, as well as inhibitors of sodium reabsorption at the renal tubules, $s E H$ is a good functional candidate gene responsible for hypertension. ${ }^{14}$ Fornage et al. ${ }^{14}$ found that mRNA expression of sEH was greatly decreased in SHRSP/Bbb (SHRSP of the Heidelberg colony) and WKY/NCrl when compared with sEH levels in WKY/Bbb and SHR/NCrl. The authors argued that the genetic variation of sEH was unlikely to contribute to the pathogenesis of hypertension in SHR, because the expression level was not in accordance with the status of hypertension among substrains of WKY and SHR. However, the fact that $\mathrm{sEH}$ mRNA expression was not consistently lower in all of the WKY-related strains compared with all of the SHR-related strains may not be enough to exclude a possible role for $\mathrm{sEH}$ in the regulation of BP.

They showed later that molecular variants in the Ephx2 promoter were responsible for the difference in sEH expression between SHRSP/ Bbb and SHR/NCrl, suggesting that low expression of sEH may be a risk factor for the stroke seen in SHRSP. ${ }^{15}$

An independent study by Monti et al. ${ }^{16}$ showed that a genetic variation in the Ephx2 promoter and the resulting change in $\mathrm{sEH}$ expression influenced the susceptibility to heart failure in SHHF, which is a model rat for heart failure derived from SHRSP.

The sEH expression was evaluated in substrains of SHR and SHRSP in several other studies. ${ }^{17-19}$ Figure 2 summarizes the results collected from these studies. As indicated, the substrains of WKY and SHR had two haplotypes of the Ephx2 gene, which lead to high and low sEH expression levels. We examined the Ephx2 haplotype and sEH mRNA expression in SHR, SHRSP and WKY/Izm rats, and confirmed that SHRSP/Izm had the same haplotype as that of SHRSP/Bbb, whereas SHR/Izm and WKY/Izm shared the haplotype with SHR/NCrl. The sEH expression levels in SHRSP/Izm and WKY/Izm were low and high, respectively, which was consistent with the pattern expected from the individual haplotype (observation by Okuda et al. ${ }^{17}$ and unpublished observation by Nabika et al.). The haplotype and expression patterns were discordant with hypertensive status among the rats examined (Figure 2). This result implied that Ephx2 was not involved in the pathogenesis of hypertension in SHR or SHRSP. In contrast, Sellers et al. ${ }^{20}$ reported that intracerebroventricular injection of an sEH inhibitor caused a significant increase in BP in SHR/NCrl, but not in WKY/NCrl. This is an interesting observation suggesting that a high sEH level in the brain of SHR opposes hypertension. In contrast, $\mathrm{sEH}$ expression was low in SHRSP, which may be responsible for the additional BP increase in this strain.

$\begin{array}{lcccccccccc} & -254 & -112 & 6769 & 13316 & 13471 & 17284 & 33121 & \text { Ephx2 exp } & \text { BP } & \text { ref. } \\ \text { SHR/Izm } & \text { T } & \text { G } & \text { T } & \text { A } & \text { A } & \text { T } & \text { A } & \text { High } & \text { High } & \text { u, } 17 \\ \text { WKY/Izm } & \text { T } & \text { G } & \text { T } & \text { A } & \text { A } & \text { T } & \text { A } & \text { High } & \text { Low } & \text { u, 17 } \\ \text { SHR/NCrl } & \text { T } & \text { G } & & \text { A } & \text { A } & \text { T } & \text { A } & \text { High } & \text { High } & 14,15,17,18 \\ \text { WKY/Bbb } 1 & & & & \text { A } & \text { A } & \text { T } & \text { A } & \text { High } & \text { Low } & 14 \\ & & & & & & & & & & \\ \text { SHRSP/Bbb } & \text { C } & \text { A } & \text { C } & \text { G } & \text { G } & \text { C } & \text { G } & \text { Low } & \text { High } & 14,16 \\ \text { SHRSP/Izm } & \text { C } & \text { A } & \text { C } & \text { G } & \text { G } & \text { C } & \text { G } & \text { Low } & \text { High } & \text { u, 17 } \\ \text { SHRSPA3 } & \text { C } & \text { A } & & & & & & \text { Low } & \text { High } & 15 \\ \text { WKY/Bbb } 1 & \text { C } & \text { A } & \text { C } & \text { G } & \text { G } & \text { C } & \text { G } & \text { Low } & \text { Low } & 16 \\ \text { WKY/NCrI } & \text { C } & \text { A } & & \text { G } & \text { G } & \text { C } & \text { G } & \text { Low } & \text { Low } & 14,17,18\end{array}$

Figure 2 Haplotypes and gene expression levels of Ephx2 in the SHRSP, SHR and WKY strains. Data were compiled from the references indicated in the figure: (1) The Ephx2 haplotype and expression pattern in WKY/Bbb appeared discrepant between Corenblum et al. ${ }^{15}$ and Monti et al. ${ }^{16}$ (2) Although the expression was low, it was still significantly greater than that of the SHRSP/Bbb. ${ }^{16} \mathrm{u}$, unpublished observation by Nabika et al. 

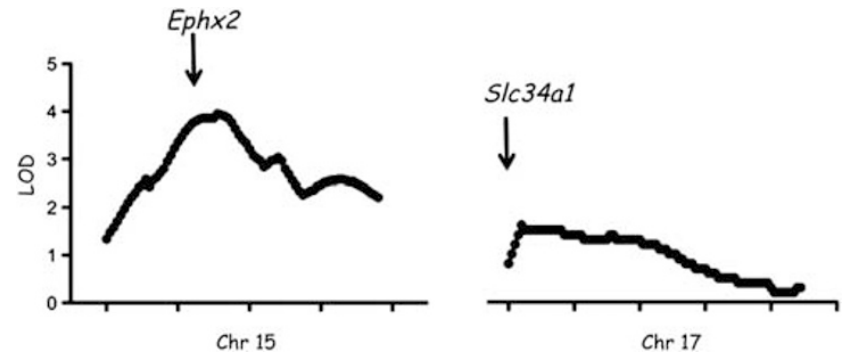

Figure 3 QTL analysis of BP in an F2 cross between SHRSP/Izm and SHR/ Izm. Lod scores for BP on Chr 15 and 17 are plotted with the location of the Ephx2 and S/c34a genes. A total of 294 F2 rats were used in the analysis (male and female data were combined).

We performed a QTL analysis on BP using an F2 cross between SHRSP/Izm and SHR/Izm. We found a suggestive peak on Chr 15, which included the Ephx2 locus (Figure 3, unpublished observation). This finding may support the role of this gene on the BP difference observed between SHR and SHRSP.

Glutathione S-transferase $\mu$-type-1 (Gstm1). McBride et al. ${ }^{21}$ found that a fragment on Chr 2 was responsible for the BP difference between SHRSP/Gcrc (SHRSP of the Glasgow colony) and WKY/ Gcrc through a QTL analysis and the subsequent congenic studies. On the basis of a comprehensive gene expression analysis using microarrays, they identified Gstm1, which had significantly lower expression in SHRSP/Gcrc, as a functional candidate gene in this chromosomal region. ${ }^{21}$ They found that the Gstm1 haplotype of SHRSP/Gcrc differed from that of WKY/Gcrc, which was responsible for a differential expression level of Gstm1 between the two strains. ${ }^{22}$

In contrast, we found that SHRSP/Izm and WKY/Izm shared the same haplotype as SHRSP/Gcrc, and no apparent difference in Gstm1 expression was observed between the two strains. This result was consistent with that of our QTL analysis, which showed no significant QTLs for BP on Chr 2 in the F2 cross between SHRSP/Izm and WKY/ Izm (data not shown).

For both of sEH and Gstm1, the haplotype and the mRNA expression level were discordant with hypertensive status when substrains of WKY and SHR/SHRSP were studied. This result did not seem to support the candidacy of those genes in BP pathogenesis. However, exclusion of these genes from the list of the candidate genes should be cautiously considered; WKY may share some hypertension genes with SHR, which may raise BP only when acting in concert with other genes (see Figure 4 and the discussion below).

Sodium-dependent phosphate transport protein $2 A$ (Slc34a1). As discussed in the first part of this review, SHR and SHRSP were derived from a small genetic pool. It is thus expected that these strains will share the same alleles in much of their genome. Doris and his colleagues ${ }^{23}$ used such identity-by-decent areas to exclude the genomic regions that do not contribute to BP differences between SHR/B2 and SHRSP/A3. Combining the identity-by-decent information with a QTL analysis, they identified a small non-identity-by-decent area on Chr 17, which could harbor a gene (or genes) contributing to the BP difference between the two strains. On the basis of comprehensive gene expression data, they further suggested that Slc34a1, a sodium/phosphate co-transporter expressed in renal tubules, was a candidate gene. ${ }^{23}$

This is a unique strategy in that they took advantage of the common genetic backgrounds shared between SHR and SHRSP.

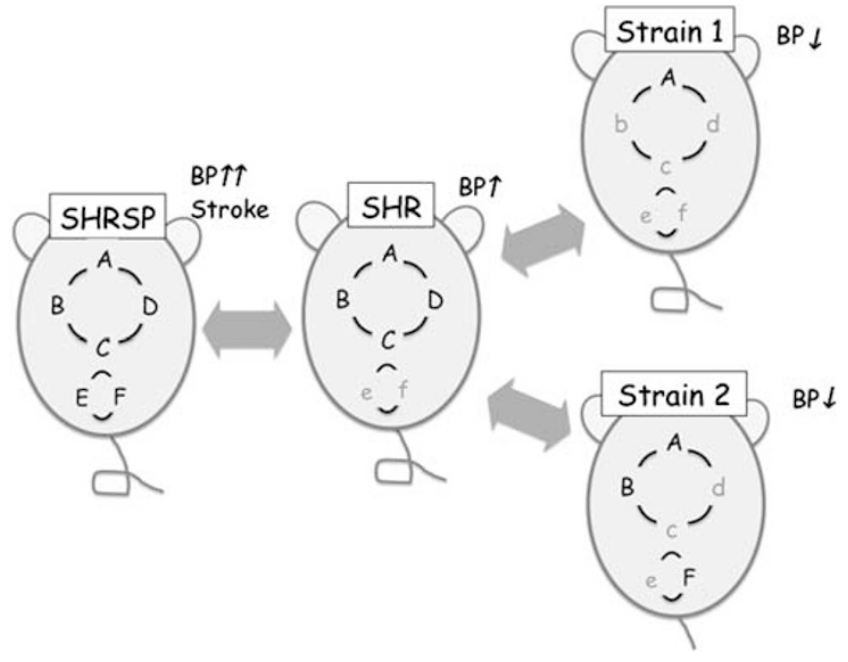

Figure 4 Hypothetical genetic composition of hypertension in SHRSP and SHR. Networks composed of multiple interacting genes are hypothesized. They have full-blown effects on BP only when all of the included genes are the 'hypertensive' allele (shown in capital letters). Consequently, even though Strain 1 harbors one hypertensive allele (' $A$ '), it is still normotensive. If SHR and Strain 1 are used in a QTL analysis, 'gene A' would not be detected as a hypertensive gene. An SHR-based congenic strain, in which allele ' $a$ ' is substituted for ' $A$ ' would have normal BP, whereas a Strain-1based congenic rat in which the allele ' $B$ ' is substituted for ' $b$ ' would not be hypertensive, because of the lack of alleles ' $C$ ' and 'D'. SHRSP may have another network that affects BP as well as stroke susceptibility.

Unfortunately, this QTL signal was not replicated in our classical QTL analysis using the F2 between SHRSP/Izm (=SHRSPA3) and SHR/Izm (=SHRB1; Figure 3). Thus, further studies are required to obtain a definite conclusion.

It is highly likely that substrains of SHR/SHRSP share many of the same alleles that promote hypertension. On the basis of this assumption, Doris and his colleagues ${ }^{24}$ attempted to identify candidate genes for hypertension by exploring genes differentially expressed between the substrains of SHR/SHRSP and those of WKY. It was rather surprising that only 36 genes were selected under this criterion. They further refined the list of candidates using other criteria concerning polymorphisms in the promoter regions and gene location to select four genes as candidates. Functional studies on these genes in hypertension are expected.

\section{Intermediate phenotype: sympathetic nerve activity}

A strong QTL for BP on Chr 1 was identified in SHRSP/Izm, which was confirmed in congenic rats. ${ }^{25-27}$ Simultaneously, our search of intermediate phenotypes indicated sympathetic hyper-responsiveness to stresses in the congenic strains constructed for this QTL. ${ }^{28-30} \mathrm{~A}$ follow-up study using preparations of isolated neonatal brain stem confirmed that the electrophysiological nature of neurons in the rostral ventrolateral medulla, one of the most important centers for sympathetic activity regulation, were influenced by the Chr 1 QTL, suggesting that rostral ventrolateral medulla is one of the primary targets of the gene(s) in this QTL. ${ }^{31}$ The congenic interval was further narrowed to a 1.8 -Mbp region on $\mathrm{Chr} 1$, in which the responsible genes are now being explored. ${ }^{32}$

If networks of interacting genes underlie the pathogenesis of hypertension, it is a difficult task to clarify them as a whole. Intermediate phenotypes may be regulated directly by the individual genes included in such 'causal networks', and it may be more feasible to 
identify genes responsible for changes in intermediate phenotypes. Of course, many intermediate phenotypes have their own complex nature as well, and this is the key to searching for adequate target phenotypes. Information about such genes for intermediate phenotypes would be a useful resource in the investigation of gene networks underlying hypertension. The most visible example of such an intermediate phenotype is expression QTLs; this method analyzes cis and trans elements of the genes regulating mRNA expression. ${ }^{33}$

\section{Stroke susceptibility}

SHRSP shows a high incidence of cerebral stroke. The incidence of spontaneous stroke is approximately $80 \%$ and reaches $100 \%$ with a high-salt diet (Okamoto et al. ${ }^{11}$ and unpublished observation). Cerebral stroke in SHRSP is not based on atherosclerosis, as is the major subtype of cerebral infarction in humans. It is, instead, similar to brain edema due to malignant hypertension and lacunar infarction, and cerebral hemorrhage caused by arteriosclerosis or hyalinosis of small arteries due to severe hypertension. ${ }^{34}$ Besides hypertension, additional genetic factors were implicated in the stroke susceptibility of SHRSP, such as neuronal vulnerability to ischemic insult, dysfunctional blood-brain barrier and arterial histological abnormalities. $^{34}$

QTL studies were performed on infarction tissue volume after artificial middle cerebral artery occlusion and stroke latency. Rubattu et al. ${ }^{35,36}$ identified QTLs for stroke latency on Chr 1, 4 and 5 in an F2 intercross between SHRSP/Bbb and SHR/Bbb, of which the QTL on Chr 1 was confirmed in congenic strains. A QTL analysis in an F2 cross between SHRSP/Gcrc and WKY/Gcrc by Jeff et al. ${ }^{37}$ showed a strong linkage of the markers on Chr 5 with the infarction volume after middle cerebral artery occlusion. Both studies indicated that the QTLs identified affected the stroke-related phenotypes independently of BP. Although the atrial natriuretic peptide gene was focused on in the Chr 5 QTL, ${ }^{37,38}$ further studies on this gene and genes in other QTLs have not yet been performed.

\section{Systematic gene expression analysis: $C d 36$}

The study on Cd36 was another seminal work that first applied comprehensive gene expression analysis in the QTL/congenic strategy, which provided a prototype for studies performed thereafter. ${ }^{39}$ Aitman et al. ${ }^{39}$ showed that an SHR/NIH derived strain had a deletion of Cd36 located in a QTL region, suggesting that this gene was contributing to insulin resistance in this strain. Using transgenic rescue studies, Pravenec et al. ${ }^{40,41}$ definitively demonstrated that genetic deficiency in the expression of $C d 36$ can contribute to both insulin resistance and increased BP in rats derived from the SHR/NIH strain. In the following studies on rats and humans, substantial evidence was accumulated supporting the role of $C d 36$ in hypertension and insulin resistance. ${ }^{42}$ On the other hand, it was reported that SHR/Izm, which is a substrain of SHR used in Japan, did not have the Cd36 deletion though it still showed insulin resistance as well as hypertension. ${ }^{43}$ This observation indicated that $C d 36$ did not have a major role in insulin resistance and hypertension in SHR/Izm. ${ }^{43,44}$ Although the role of $C d 36$ in insulin resistance was not denied, further studies on the insulin resistance in SHR are necessary to obtain a comprehensive view of this issue.

\section{ROLE OF GENETIC ANALYSIS OF SHR AND SHRSP IN THE POST-GWAS ERA}

As discussed above, it is quite common that genetic analyses gave discrepant results when different sets of SHR/SHRSP and normotensive rat strains were employed.
If the goal of QTL analyses is set to identify candidate genes in rat models, the inconsistency among the QTL studies does not matter; identified genes in rats are examined as candidates in humans anyway. Ten years ago, we did not have the tools to dissect candidate genes from the human genome, and thus, the candidate genes found in rats gave us important clues. In contrast, we are now able to extract many candidate genes (or single-nucleotide polymorphisms) directly from the human genome through large-scale GWAS. ${ }^{3-10}$ If species differences between rodents and humans are considered, the importance of genetic model rats as a 'supplier' of candidate genes is relatively diminished.

Under such conditions, what is the role of genetic analyses in SHR/ SHRSP? To answer this question, it may be useful to focus on the genetic composition of hypertension in SHR/SHRSP.

There are four possible models for this application:

(a) Single gene model: This is not likely if accumulated results of classical segregation studies as well as a number of QTL analyses are taken into consideration.

(b) Polygenic additive model: This assumes many weak causative genes distributed throughout the genome, which affect BP in an additive manner. This model is currently assumed in human GWAS. In the case of SHR/SHRSP, this model is not likely when only two to three generations were necessary to achieve substantial increases in BP during the original development process. ${ }^{45}$

(c) Oligogenic additive model: A limited number of causative genes with large effects additively contribute to hypertension. This may be applicable to SHR/SHRSP; however, under this model, asymmetrical effects of some QTLs in reciprocal congenic strains may be difficult to interpret (Figure 5a).

(d) Oligogenic synergistic model: Synergistic interactions among a few genes are required. This model may be the best to describe the genetic composition of hypertension in SHR/SHRSP. Many studies on congenic strains suggested that one QTL was composed of several genes interacting with one another. ${ }^{46}$ In spite of a lack of sufficient evidence, similar interactions can be hypothesized among QTLs on separate chromosomes.

If hypertension in SHR/SHRSP is realized under the model (D), it is less useful to examine the individual candidate gene identified in SHR/ SHRSP in the current genetic studies performed in humans, because in GWAS and other genetic studies in humans, gene-gene interactions are not generally considered. Instead, SHR/SHRSP needs to be analyzed as 'a total gene network' underlying hypertension and cardiovascular complications.

According to the National BioResource Project for the Rat database, SHRSP is the strain showing the highest BP among 179 strains. ${ }^{47}$ This finding implies that SHRSP has a unique set of hypertension genes that makes it distinct from any other rat strain. Although some genes in this set may be shared with other strains, it is likely that gene-gene interactions are necessary for these genes to manifest a full-blown effect on BP (Figure 4).

It is, therefore, vital to clarify the gene network as a whole in SHRSP rather than to identify individual candidate genes. Knowledge about such a network will be useful to reveal the pathogenesis of human hypertension even if the individual genes involved in the network are not identical.

Still, many single-nucleotide polymorphisms influencing BP have been identified in human GWAS, and there are strong arguments against the clinical significance of these single-nucleotide polymorphisms due to 
a

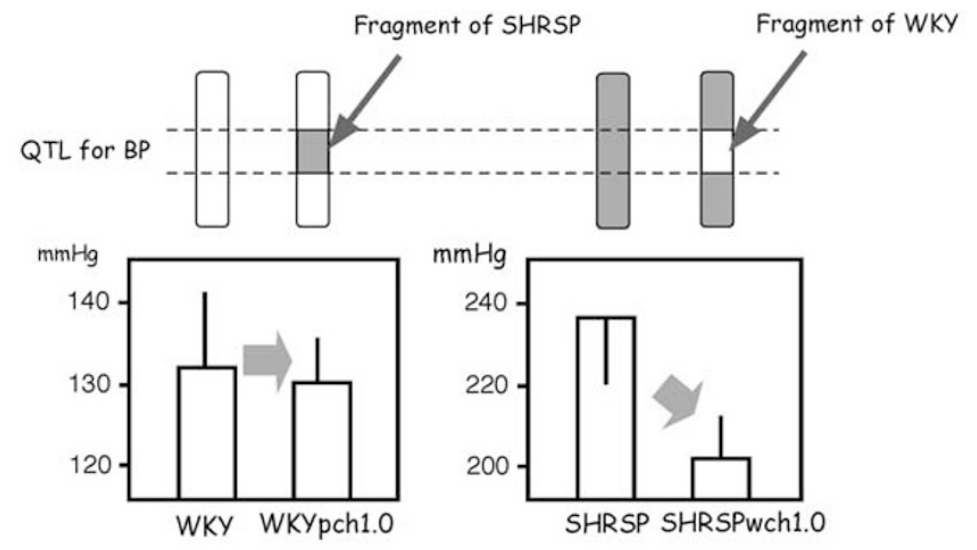

b

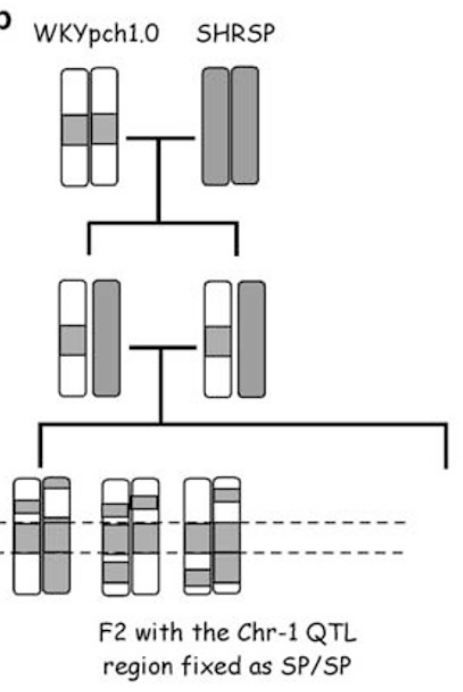

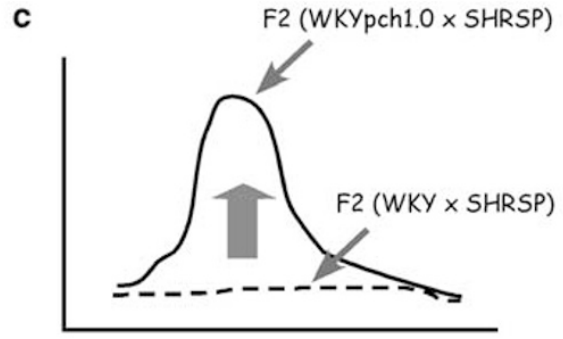

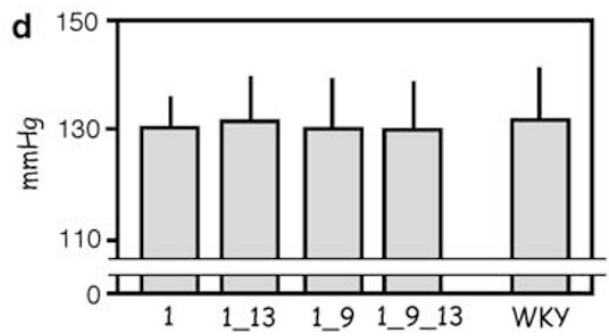

Figure 5 A trial to show interactions among QTLS in SHRSP. (a) Reciprocal congenic rats for the Chr 1 QTL do not show reciprocal effects of the QTL on BP. WKYpch1.0 and SHRSPwch1.0 are reciprocal congenic strains constructed for the Chr 1 QTL. ${ }^{29,31,32}$ (b) The study design of a QTL analysis using a congenic rat (WKYpch1.0) and SHRSP. In all the F2 rats, the Chr 1 QTL is fixed as homozygous for the SHRSP allele. (c) An expected, result of the QTL analysis illustrated in (b). A new QTL may appear only in the F2 between the congenic rat (WKYpch1.0) and SHRSP, because of the requirement of interactions with the Chr 1 QTL. (d) BP of double and triple congenic rats. On the basis of the QTL analysis shown in (b), double congenic rats for Chr 1 and 9 (shown as 1_9) and for Chr 1 and 13 (1_13) QTLs and a triple congenic rat for the three QTLs (1_9_13) were constructed. Evaluation of BP indicated that no significant rise in BP was observed in these congenic strains.

their weak effects. ${ }^{48,49}$ If a network of interacting genes is shown to be essential in the pathogenesis of hypertension in rats, it may provide new insights into the pathogenic mechanisms of human hypertension.

In this regard, whole-genome sequencing of multiple rat strains, including several SHR and SHRSP substrains, which is ongoing in the EuraTrans project (http://www.euratrans.eu/), will provide useful information. A comprehensive analysis of the genome sequence combined with the analysis of a gene expression network recently succeeded in identifying a new gene responsible for type I diabetes mellitus. ${ }^{50} \mathrm{~A}$ similar bioinformatics strategy may be able to dissect the network underlying hypertension in SHR/SHRSP. ${ }^{19,51}$

In addition to such bioinformatics studies, another tool may be useful to promote physiological, cell biological and biochemical studies: a 'reconstructed' SHR with a few genomic fragments of SHR/SHRSP on the WKY background.

The initial process of development of SHR as well as a classical segregation study by Tanase et al. ${ }^{52}$ suggested that only a limited number of genetic loci (or QTLs) were involved in hypertension in SHR. ${ }^{45}$ This observation implies that the appropriate combination of several genomic regions of SHR/SHRSP can 'reconstruct' hypertension on the WKY background to some extent. Such a 'reconstructed' SHR/SHRSP can then be used to evaluate the effects of interacting QTLs on various biochemical and physiological processes in combination with WKY.

To test this possibility, we performed a QTL analysis on an F2 cohort constructed by crossing WKYpch1.0 (a WKY-based congenic strain for the Chr 1 QTL) and SHRSP. Under this study design, the Chr 1 QTL was fixed as homozygous for the SHRSP allele in all the F2 progenies; and thus, additional detected QTLs would be those interacting with the Chr 1 QTL (Figure $5 \mathrm{~b}$ and $\mathrm{c}$ ). The results indicated that two regions on Chr 9 and 13 showed a weakly suggestive linkage with BP (unpublished observation). However, as these linkage signals were detected in an F2 cross between WKY and SHRSP, it did not seem that these QTLs interacted with the Chr 1 QTL originally identified. In fact, a confirmation study using double and triple congenic strains for these QTLs showed no apparent increase in BP, translating to a failure of 'reconstructing' SHR on the WKY background (Figure 5d, unpublished observation). This result may 
indicate that complex interactions between more than two QTLs are necessary to raise BP. We continue the attempt to 'reconstruct' SHR in our laboratory.

\section{CONCLUSIONS}

SHRSP will continue to have an important role in the genetic research of hypertension, if the putative networks of interacting genes in this model become better understood. To obtain direct and more convincing evidence, additional information and resources for better understanding of the genetic and genomic architecture of SHR/SHRSP are required.

\section{CONFLICT OF INTEREST}

The authors declare no conflict of interest.

\section{ACKNOWLEDGEMENTS}

This work was partly supported by the Grant-in-Aid for Scientific Research by the Japanese Ministry of Education, Science, Sports and Culture.

1 Hilbert P, Lindpaintner K, Beckmann JS, Serikawa T, Soubrier F, Dubay C, Cartwright P, De Gouyon B, Julier C, Takahasi S, Vincent M, Ganten D, Georges M, Lathrop GM. Chromosomal mapping of two genetic loci associated with blood-pressure regulation in hereditary hypertensive rats. Nature 1991; 353: 521-529.

2 Jacob HJ, Lindpaintner K, Lincoln SE, Kusumi K, Bunker RK, Mao YP, Ganten D, Dzau VJ, Lander ES. Genetic mapping of a gene causing hypertension in the stroke-prone spontaneously hypertensive rat. Cell 1991; 67: 213-224.

3 International Consortium for Blood Pressure Genome-Wide Association Studies; CARDIoGRAM consortium; CKDGen Consortium; KidneyGen Consortium; EchoGen consortium; CHARGE-HF consortium, Ehret GB, Munroe PB, Rice KM, Bochud M, Johnson AD, Chasman DI, Smith AV, Tobin MD, Verwoert GC, Hwang SJ, Pihur V, Vollenweider P, O'Reilly PF, Amin N, Bragg-Gresham JL, Teumer A, Glazer NL, Launer L, Zhao JH, Aulchenko Y, Heath S, Sõber S, Parsa A, Luan J, Arora P, Dehghan A, Zhang F, Lucas G, Hicks AA, Jackson AU, Peden JF, Tanaka T, Wild SH, Rudan I, Igl W, Milaneschi Y, Parker AN, Fava C, Chambers JC, Fox ER, Kumari M, Go MJ, van der Harst P, Kao WH, Sjögren M, Vinay DG, Alexander M, Tabara Y, Shaw-Hawkins S, Whincup PH, Liu Y, Shi G, Kuusisto J, Tayo B, Seielstad M, Sim X, Nguyen KD, Lehtimäki T, Matullo G, Wu Y, Gaunt TR, Onland-Moret NC, Cooper MN, Platou CG, Org E, Hardy R, Dahgam S, Palmen J, Vitart V, Braund PS, Kuznetsova T, Uiterwaal CS, Adeyemo A, Palmas W, Campbell H, Ludwig B, Tomaszewski M, Tzoulaki I, Palmer ND, Aspelund T, Garcia M, Chang YP, O'Connell JR, Steinle NI, Grobbee DE, Arking DE, Kardia SL, Morrison AC, Hernandez D, Najjar S, McArdle WL, Hadley D, Brown MJ, Connell JM, Hingorani AD, Day IN, Lawlor DA, Beilby JP, Lawrence RW, Clarke R, Hopewell JC, Ongen H, Dreisbach AW, Li Y, Young JH, Bis JC, Kähönen M, Viikari J, Adair LS, Lee NR, Chen MH, Olden M, Pattaro C, Bolton JA, Köttgen A, Bergmann S, Mooser V, Chaturvedi N, Frayling TM, Islam M, Jafar TH, Erdmann J, Kulkarni SR, Bornstein SR, Grässler J, Groop L, Voight BF, Kettunen J, Howard P, Taylor A, Guarrera S, Ricceri F, Emilsson V, Plump A, Barroso I, Khaw KT, Weder AB, Hunt SC, Sun YV, Bergman RN, Collins FS, Bonnycastle LL, Scott LJ, Stringham HM, Peltonen L, Perola M, Vartiainen E, Brand SM, Staessen JA, Wang TJ, Burton PR, Artigas MS, Dong Y, Snieder H, Wang X, Zhu H, Lohman KK, Rudock ME, Heckbert SR, Smith NL, Wiggins KL, Doumatey A, Shriner D, Veldre G, Viigimaa M, Kinra S, Prabhakaran D, Tripathy V, Langefeld CD, Rosengren A, Thelle DS, Corsi AM, Singleton A, Forrester T, Hilton G, McKenzie CA, Salako T, Iwai N, Kita Y, Ogihara T, Ohkubo T, Okamura T, Ueshima H, Umemura S, Eyheramendy S, Meitinger T, Wichmann HE, Cho YS, Kim HL, Lee JY, Scott J, Sehmi JS, Zhang W, Hedblad B, Nilsson P, Smith GD, Wong A, Narisu N, Stanèáková A, Raffel LJ, Yao J, Kathiresan S, O'Donnell CJ, Schwartz SM, Ikram MA, Longstreth Jr WT, Mosley TH, Seshadri S, Shrine NR, Wain LV, Morken MA, Swift AJ, Laitinen J, Prokopenko I, Zitting P, Cooper JA, Humphries SE, Danesh J, Rasheed A, Goel A, Hamsten A, Watkins H, Bakker SJ, van Gilst WH, Janipalli CS, Mani KR, Yajnik CS, Hofman A, Mattace-Raso FU, Oostra BA, Demirkan A, Isaacs A, Rivadeneira F, Lakatta EG, Orru M, Scuteri A, AlaKorpela M, Kangas AJ, Lyytikäinen LP, Soininen P, Tukiainen T, Würtz P, Ong RT, Dörr M, Kroemer HK, Völker U, Völzke H, Galan P, Hercberg S, Lathrop M, Zelenika D, Deloukas P, Mangino M, Spector TD, Zhai G, Meschia JF, Nalls MA, Sharma P, Terzic J, Kumar MV, Denniff M, Zukowska-Szczechowska E, Wagenknecht LE, Fowkes FG, Charchar FJ, Schwarz PE, Hayward C, Guo X, Rotimi C, Bots ML, Brand E, Samani NJ, Polasek O, Talmud PJ, Nyberg F, Kuh D, Laan M, Hveem K, Palmer LJ, van der Schouw YT, Casas JP, Mohlke KL, Vineis P, Raitakari O, Ganesh SK, Wong TY, Tai ES, Cooper RS, Laakso M, Rao DC, Harris TB, Morris RW, Dominiczak AF, Kivimaki M, Marmot MG, Miki T, Saleheen D, Chandak GR, Coresh J, Navis G, Salomaa V, Han BG, Zhu X, Kooner JS, Melander O, Ridker PM, Bandinelli S, Gyllensten UB, Wright AF, Wilson JF, Ferrucci L, Farrall M, Tuomilehto J, Pramstaller PP, Elosua R, Soranzo N, Sijbrands EJ, Altshuler D, Loos RJ, Shuldiner AR, Gieger C, Meneton P, Uitterlinden AG, Wareham NJ, Gudnason V, Rotter JI, Rettig R, Uda M, Strachan DP, Witteman JC,
Hartikainen AL, Beckmann JS, Boerwinkle E, Vasan RS, Boehnke M, Larson MG, Järvelin MR, Psaty BM, Abecasis GR, Chakravarti A, Elliott P, van Duijn CM, NewtonCheh C, Levy D, Caulfield MJ, Johnson T, Tang H, Knowles J, Hlatky M, Fortmann S, Assimes TL, Quertermous T, Go A, Iribarren C, Absher D, Risch N, Myers R, Sidney S, Ziegler A, Schillert A, Bickel C, Sinning C, Rupprecht HJ, Lackner K, Wild P, Schnabel R, Blankenberg S, Zeller T, Münzel T, Perret C, Cambien F, Tiret L, Nicaud V, Proust C, Dehghan A, Hofman A, Uitterlinden A, van Duijn C, Levy D, Whitteman J, Cupples LA, Demissie-Banjaw S, Ramachandran V, Smith A, Gudnason V, Boerwinkle E, Folsom A, Morrison A, Psaty BM, Chen IY, Rotter JI, Bis J, Volcik K, Rice K, Taylor KD, Marciante K, Smith N, Glazer N, Heckbert S, Harris T, Lumley T, Kong A, Thorleifsson G, Thorgeirsson G, Holm H, Gulcher JR, Stefansson K, Andersen K, Gretarsdottir S, Thorsteinsdottir U, Preuss M, Schreiber S, Meitinger T, König IR, Lieb W, Hengstenberg C, Schunkert H, Erdmann J, Fischer M, Grosshennig A, Medack A, Stark K, Linsel-Nitschke P, Bruse P, Aherrahrou Z, Peters A, Loley C, Willenborg C, Nahrstedt J, Freyer J, Gulde S, Doering A, Meisinger C, Wichmann HE, Klopp N, Illig T, Meinitzer A, Tomaschitz A, Halperin E, Dobnig H, Scharnagl H, Kleber M, Laaksonen R, Pilz S, Grammer TB, Stojakovic T, Renner W, März W, Böhm BO, Winkelmann BR, Winkler K, Hoffmann MM, O'Donnell CJ, Voight BF, Altshuler D, Siscovick DS, Musunuru K, Peltonen L, Barbalic M, Melander O, Elosua R, Kathiresan S, Schwartz SM, Salomaa V, Guiducci C, Burtt N, Gabriel SB, Stewart AF, Wells GA, Chen L, Jarinova O, Roberts R, McPherson R, Dandona S, Pichard AD, Rader DJ, Devaney J, Lindsay JM, Kent KM, Qu L, Satler L, Burnett MS, Li M, Reilly MP, Wilensky R, Waksman R, Epstein S, Matthai W, Knouff CW, Waterworth DM, Hakonarson HH, Walker MC, Mooser V, Hall AS, Balmforth AJ, Wright BJ, Nelson C, Thompson JR, Samani NJ, Braund PS, Ball SG, Smith NL, Felix JF, Morrison AC, Demissie S, Glazer NL, Loehr LR, Cupples LA, Dehghan A, Lumley T, Rosamond WD, Lieb W, Rivadeneira F, Bis JC, Folsom AR, Benjamin E, Aulchenko YS, Haritunians T, Couper D, Murabito J, Wang YA, Stricker BH, Gottdiener JS, Chang PP, Wang TJ, Rice KM, Hofman A, Heckbert SR, Fox ER, O'Donnell CJ, Uitterlinden AG, Rotter JI, Willerson JT, Levy D, van Duijn CM, Psaty BM, Witteman JC, Boerwinkle E, Vasan RS, Köttgen A, Pattaro C, Böger CA, Fuchsberger C, Olden M, Glazer NL, Parsa A, Gao X, Yang Q, Smith AV, O'Connell JR, Li M, Schmidt H, Tanaka T, Isaacs A, Ketkar S, Hwang SJ, Johnson AD, Dehghan A, Teumer A, Paré G, Atkinson EJ, Zeller T, Lohman K, Cornelis MC, Probst-Hensch NM, Kronenberg F, Tönjes A, Hayward C, Aspelund T, Eiriksdottir G, Launer LJ, Harris TB, Rampersaud E, Mitchell BD, Arking DE, Boerwinkle E, Struchalin M, Cavalieri M, Singleton A, Giallauria F, Metter J, de Boer J, Haritunians T, Lumley T, Siscovick D, Psaty BM, Zillikens MC, Oostra BA, Feitosa M, Province M, de Andrade M, Turner ST, Schillert A, Ziegler A, Wild PS, Schnabel RB, Wilde S, Munzel TF, Leak TS, IIlig T, Klopp N, Meisinger C, Wichmann HE, Koenig W, Zgaga L, Zemunik T, Kolcic I, Minelli C, Hu FB, Johansson A, IgI W, Zaboli G, Wild SH, Wright AF, Campbell H, Ellinghaus $D$, Schreiber S, Aulchenko YS, Felix JF, Rivadeneira F, Uitterlinden AG, Hofman A, Imboden $M$, Nitsch $D$, Brandstätter $A$, Kollerits $B$, Kedenko L, Mägi R, Stumvoll M, Kovacs P, Boban M, Campbell S, Endlich K, Völzke H, Kroemer HK, Nauck M, Völker U, Polasek O, Vitart V, Badola S, Parker AN, Ridker PM, Kardia SL, Blankenberg S, Liu Y, Curhan GC, Franke A, Rochat T, Paulweber B, Prokopenko I, Wang W, Gudnason V, Shuldiner AR, Coresh J, Schmidt R, Ferrucci L, Shlipak MG, van Duijn CM, Borecki I, Krämer BK, Rudan I, Gyllensten U, Wilson JF, Witteman JC, Pramstaller PP, Rettig R, Hastie N, Chasman DI, Kao WH, Heid IM, Fox CS, Vasan RS, Glazer NL, Felix JF, Lieb W, Wild PS, Felix SB, Watzinger N, Larson MG, Smith NL, Dehghan A, Grosshennig A, Schillert A, Teumer A, Schmidt R, Kathiresan S, Lumley T, Aulchenko YS, König IR, Zeller T, Homuth G, Struchalin M, Aragam J, Bis JC, Rivadeneira F, Erdmann J, Schnabel RB, Dörr M, Zweiker R, Lind L, Rodeheffer RJ, Greiser KH, Levy D, Haritunians T, Deckers JW, Stritzke J, Lackner KJ, Völker U, Ingelsson E, Kullo I, Haerting J, O'Donnell CJ, Heckbert SR, Stricker BH, Ziegler A, Reffelmann T, Redfield MM, Werdan K, Mitchell GF, Rice K, Arnett DK, Hofman A, Gottdiener JS, Uitterlinden AG, Meitinger T, Blettner M, Friedrich N, Wang TJ, Psaty BM, van Duijn CM, Wichmann HE, Munzel TF, Kroemer HK, Benjamin EJ, Rotter JI, Witteman JC, Schunkert H, Schmidt H, Völzke H, Blankenberg S, Chambers JC, Zhang W, Lord GM, van der Harst P, Lawlor DA, Sehmi JS, Gale DP, Wass MN, Ahmadi KR, Bakker SJ, Beckmann J, Bilo HJ, Bochud M, Brown MJ, Caulfield MJ, Connell JM, Cook HT, Cotlarciuc I, Davey Smith G, de Silva R, Deng G, Devuyst O, Dikkeschei LD, Dimkovic N, Dockrell M, Dominiczak A, Ebrahim S, Eggermann T, Farrall M, Ferrucci L, Floege J, Forouhi NG, Gansevoort RT, Han X, Hedblad B, Homan van der Heide JJ, Hepkema BG, Hernandez-Fuentes M, Hypponen E, Johnson T, de Jong PE, Kleefstra N, Lagou V, Lapsley M, Li Y, Loos RJ, Luan J, Luttropp K, Maréchal C, Melander O, Munroe PB, Nordfors L, Parsa A, Peltonen L, Penninx BW, Perucha E, Pouta A, Prokopenko I, Roderick PJ, Ruokonen A, Samani NJ, Sanna S, Schalling M, Schlessinger D, Schlieper G, Seelen MA, Shuldiner AR, Sjögren M, Smit JH, Snieder H, Soranzo N, Spector TD, Stenvinkel P, Sternberg MJ, Swaminathan R, Tanaka T, Ubink-Veltmaat LJ, Uda M, Vollenweider P, Wallace C, Waterworth D, Zerres K, Waeber G, Wareham NJ, Maxwell PH, McCarthy MI, Jarvelin MR, Mooser V, Abecasis GR, Lightstone L, Scott J, Navis G, Elliott P, Kooner JS. Genetic variants in novel pathways influence blood pressure and cardiovascular disease risk. Nature 2011; 478: 103-109.

4 Kato N, Takeuchi F, Tabara Y, Kelly TN, Go MJ, Sim X, Tay WT, Chen CH, Zhang Y, Yamamoto K, Katsuya T, Yokota M, Kim YJ, Ong RT, Nabika T, Gu D, Chang LC, Kokubo Y, Huang W, Ohnaka K, Yamori Y, Nakashima E, Jaquish CE, Lee JY, Seielstad M, Isono M, Hixson JE, Chen YT, Miki T, Zhou X, Sugiyama T, Jeon JP, Liu JJ, Takayanagi R, Kim SS, Aung T, Sung YJ, Zhang X, Wong TY, Han BG, Kobayashi S, Ogihara T, Zhu D, Iwai N, Wu JY, Teo YY, Tai ES, Cho YS, He J. Meta-analysis of genome-wide association studies identifies common variants associated with blood pressure variation in east Asians. Nat Genet 2011; 43: 531-538.

5 Padmanabhan S, Melander O, Johnson T, Di Blasio AM, Lee WK, Gentilini D, Hastie CE, Menni C, Monti MC, Delles C, Laing S, Corso B, Navis G, Kwakernaak AJ, van der Harst 
P, Bochud M, Maillard M, Burnier M, Hedner T, Kjeldsen S, Wahlstrand B, Sjögren M, Fava C, Montagnana M, Danese E, Torffvit O, Hedblad B, Snieder H, Connell JM, Brown M, Samani NJ, Farrall M, Cesana G, Mancia G, Signorini S, Grassi G, Eyheramendy S, Wichmann HE, Laan M, Strachan DP, Sever P, Shields DC, Stanton A, Vollenweider P, Teumer A, Völzke H, Rettig R, Newton-Cheh C, Arora P, Zhang F, Soranzo N, Spector TD, Lucas G, Kathiresan S, Siscovick DS, Luan J, Loos RJ, Wareham NJ, Penninx BW, Nolte IM, McBride M, Miller WH, Nicklin SA, Baker AH, Graham D, McDonald RA, Pell JP, Sattar N, Welsh P, Munroe P, Caulfield MJ, Zanchetti A, Dominiczak AF. Genome-wide association study of blood pressure extremes identifies variant near UMOD associated with hypertension. PLoS Genet 2010; 6: e1001177.

6 Tabara Y, Kohara K, Kita Y, Hirawa N, Katsuya T, Ohkubo T, Hiura Y, Tajima A, Morisaki T, Miyata T, Nakayama T, Takashima N, Nakura J, Kawamoto R, Takahashi N, Hata A, Soma M, Imai Y, Kokubo Y, Okamura T, Tomoike H, Iwai N, Ogihara T, Inoue I, Tokunaga $\mathrm{K}$, Johnson T, Caulfield M, Munroe P, Umemura S, Ueshima H, Miki T. Common variants in the ATP2B1 gene are associated with susceptibility to hypertension: the Japanese Millennium Genome Project. Hypertension 2010; 56: 973-980.

7 Newton-Cheh C, Johnson T, Gateva V, Tobin MD, Bochud M, Coin L, Najiar SS, Zhao JH, Heath SC, Eyheramendy S, Papadakis K, Voight BF, Scott LJ, Zhang F, Farrall M, Tanaka T, Wallace C, Chambers JC, Khaw KT, Nilsson P, van der Harst P, Polidoro S, Grobbee DE, Onland-Moret NC, Bots ML, Wain LV, Elliott KS, Teumer A, Luan J, Lucas G, Kuusisto J, Burton PR, Hadley D, McArdle WL, Brown M, Dominiczak A, Newhouse SJ, Samani NJ, Webster J, Zeggini E, Beckmann JS, Bergmann S, Lim N, Song K, Vollenweider P, Waeber G, Waterworth DM, Yuan X, Groop L, Orho-Melander M, Allione A, Di Gregorio A, Guarrera S, Panico S, Ricceri F, Romanazzi V, Sacerdote C, Vineis $P$, Barroso I, Sandhu MS, Luben RN, Crawford GJ, Jousilahti P, Perola M, Boehnke M, Bonnycastle LL, Collins FS, Jackson AU, Mohlke KL, Stringham HM, Valle TT, Willer CJ, Bergman RN, Morken MA, Döring A, Gieger C, Illig T, Meitinger T, Org E, Pfeufer A, Wichmann HE, Kathiresan S, Marrugat J, O'Donnell CJ, Schwartz SM, Siscovick DS, Subirana I, Freimer NB, Hartikainen AL, McCarthy MI, O'Reilly PF, Peltonen L, Pouta A, de Jong PE, Snieder H, van Gilst WH, Clarke R, Goel A, Hamsten A, Peden JF, Seedorf U, Syvänen AC, Tognoni G, Lakatta EG, Sanna S, Scheet P, Schlessinger D, Scuteri A, Dörr M, Ernst F, Felix SB, Homuth G, Lorbeer R, Reffelmann T, Rettig R, Völker U, Galan P, Gut IG, Hercberg S, Lathrop GM, Zelenika D, Deloukas P, Soranzo N, Williams FM, Zhai G, Salomaa V, Laakso M, Elosua R, Forouhi NG, Völzke H, Uiterwaal CS, van der Schouw YT, Numans ME, Matullo G, Navis G, Berglund G, Bingham SA, Kooner JS, Connell JM, Bandinelli S, Ferrucci L, Watkins H, Spector TD, Tuomilehto J, Altshuler D, Strachan DP, Laan M, Meneton P, Wareham NJ, Uda M, Jarvelin MR, Mooser V, Melander O, Loos RJ, Elliott P, Abecasis GR, Caulfield M, Munroe PB. Genome-wide association study identifies eight loci associated with blood pressure. Nat Genet 2009; 41: 666-676.

8 Levy D, Ehret GB, Rice K, Verwoert GC, Launer LJ, Dehghan A, Glazer NL, Morrison AC, Johnson AD, Aspelund T, Aulchenko Y, Lumley T, Köttgen A, Vasan RS, Rivadeneira F, Eiriksdottir G, Guo X, Arking DE, Mitchell GF, Mattace-Raso FU, Smith AV, Taylor K, Scharpf RB, Hwang SJ, Sijbrands EJ, Bis J, Harris TB, Ganesh SK, O'Donnell CJ, Hofman A, Rotter JI, Coresh J, Benjamin EJ, Uitterlinden AG, Heiss G, Fox CS, Witteman JC, Boerwinkle E, Wang TJ, Gudnason V, Larson MG, Chakravarti A, Psaty $\mathrm{BM}$, van Duijn CM. Genome-wide association study of blood pressure and hypertension. Nat Genet 2009; 41: 677-687.

9 Cho YS, Go MJ, Kim YJ, Heo JY, Oh JH, Ban HJ, Yoon D, Lee MH, Kim DJ, Park M, Cha SH, Kim JW, Han BG, Min H, Ahn Y, Park MS, Han HR, Jang HY, Cho EY, Lee JE, Cho NH, Shin C, Park T, Park JW, Lee JK, Cardon L, Clarke G, McCarthy MI, Lee JY, Lee JK, Oh B, Kim HL. A large-scale genome-wide association study of Asian populations uncovers genetic factors influencing eight quantitative traits. Nat Genet 2009; 41: $527-534$

10 Wellcome Trust Case-Control Consortium. Genome-wide association study of 14000 cases of seven common diseases and 3000 shared controls. Nature 2007; 447: 661678.

11 Okamoto K, Yamori Y, Nagaoka A. Establishment of stroke-prone spontaneously hypertensive rat (SHR). Circ Res 1974; 34/35: I143-I153.

12 Mashimo T, Voigt B, Tsurumi T, Naoi K, Nakanishi S, Yamasaki K, Kuramoto T, Serikawa T. A set of highly informative rat simple sequence length polymorphism (SSLP) markers and genetically defined rat strains. BMC Genet 2006; 7: 19.

13 Twigger SN, Shimoyama M, Bromberg S, Kwitek AE, Jacob HJ. The rat genome database, update 2007-easing the path from disease to data and back again. NuCl Acids Res 2007; 35: D658-D662.

14 Fornage M, Hinojos CA, Nurowska BW, BOerwinkle E, Hammock BD, Morisseau CHP, Doris PA. Polymorphsim in soluble epoxide hydrolase and blood pressure in spontaneously hypertensive rats. Hypertension 2002; 40: 485-490.

15 Corenblum MJ, Wise VE, Georgi K, Hammock BD, Doris PA, Fornage M. Altered soluble epoxide hydrolase gene expression and function and vascular disease risk in the stroke-prone spontaneously hypertensive rat. Hypertnsion 2008; 51: 567-573.

16 Monti J, Fischer J, Paskas S, Heinig M, Schulz H, Gösele C, Heuser A, Fischer R, Schmidt C, Schirdewan A, Gross V, Hummel O, Maatz H, Patone G, Saar K, Vingron M, Weldon SM, Lindpaintner K, Hammock BD, Rohde K, Dietz R, Cook SA, Schunck WH, Luft FC, Hubner N. Soluble epoxide hydrolase is a susceptibility factor for heart failure in a rat model of human disease. Nat Genet 2008; 40: 529-537.

17 Okuda T, Sumiya T, Iwai N, Miyata T. Difference of gene expression profiles in spontaneously hypertensive rats and Wistar-Kyoto rats from two sources. Biochem Biophys Res Commun 2002; 296: 537-543.

18 Seubert JM, Xu F, Graves JP, Collins JB, Sieber SO, Paules RS, Droetz DL, Zeldin DC. Differential renal gene expression in prehypertensive and hypertensive spontaneously hypertensive rats. Am J Physiol 2005; 289: F552-F561.
19 Hinojos CA, Boerwinkle E, Fornage M, Doris PA. Combined genealogical, mapping, and expression approaches to identify spontaneously hypertensive rat hypertension candidate genes. Hypertension 2005; 45: 698-704.

20 Sellers KW, Sun C, Diez-Freire C, Waki H, Morisseau C, Falck JR, Hammock BD, Paton JF, Raizada MK. Novel mechanism of brain soluble epoxide hydrolase-mediated blood pressure regulation in the spontaneously hypertensive rat. FASEB J 2005; 19 : 626-628.

21 McBride M, Carr FJ, Graham D, Anderson NH, Clark JS, Lee WK, Charchar FJ, Brosnan MJ, Dominiczak AF. Microarray analysis of rat chromosome 2 congenic strains. Hypertension 2003; 41: 847-853.

22 McBride MW, Brosnan MJ, Mathers J, McLellan LI, Miller WH, Graham D, Hanlon N, Hamilton CA, Polke JM, Lee WK, Dominiczak AF. Reduction of Gstm1 expression in the stroke-prone spontaneously hypertensive rat contributes to increased oxidative stress. Hypertension 2005; 45: 786-795.

23 Bell R, Herring SM, Gokul N, Monita M, Grove ML, Boerwinkle E, Doris PA. Highresolution identity by descent mapping uncovers the genetic basis for blood pressure differences between spontaneously hypertensive rat lines. Circ Cardiovasc Genet 2011; 4: 223-231.

24 Dmitrieva RI, Hinojos CA, Grove ML, Bell RJ, Boerwinkle E, Fornage M, Doris PA. Genome-wide indentification of allelic expression in hypertensive rats. Circ Cardiovasc Genet 2009; 2: 106-115.

25 Mashimo T, Nabika T, Matsumoto C, Tamada T, Ueno K, Sawamura M, Ikeda K, Kato N, Nara Y, Yamori Y. Aging and salt-loading modulate blood pressure QTLs in rats. Am J Hypertens 1999; 12: 1098-1104.

26 Kato N, Mashimo T, Nabika T, Cui ZH, Ikeda K, Yamori Y. Genome-wide searches for blood pressure quantitative trait loci in the stroke-prone spontaneously hypertensive rat of a Japanese colony. J Hypertens 2003; 21: 295-303.

27 Kato N, Nabika T, Liang Y-Q, Mashimo T, Inomata H, Watanabe T, Yanai K, Yamori Y, Yazaki $Y$, Sasazuki T. Isolation of a chromosome 1 region affecting blood pressure and vascular disease traits in the stroke-prone rat model. Hypertension 2003; 42: 1191-1197.

28 Cui ZH, Ikeda K, Kawakami K, Gonda T, Nabika T, Masuda J. Exaggerated response to restraint stress in rats congenic for chromosome 1 blood pressure quantitative trait locus. Clin Exp Pharmacol Physiol 2003; 30: 464-469.

29 Cui ZH, Ikeda K, Kawakami K, Gonda T, Masuda J, Nabika T. Exaggerated response to cold stress in a congenic strain for the quantitative trait locus for blood pressure. J Hypertens 2004; 22: 2103-2109.

30 Yamazato M, Ohya Y, Nakamoto M, Sakima A, Tagawa T, Harada Y, Nabika T, Takishita S. Sympathetic hyperreactivity to air-jet stress in the choromosome 1 blood pressure quantitative trait locus congenic rats. Am J Physiol 2006; 290: R709-R714.

31 ligaya K, Kumagai H, Nabika T, Harada Y, Onimaru H, Oshima N, Takimoto C, Kamayachi T, Saruta T, Itoh H. Relation of blood pressure quantitative trait locus on rat chromosome 1 to hyperactivity of rostral ventrolateral medulla. Hypertension 2009; 53: 42-48.

32 Xiao B, Harada Y, Kawakami K, Nabika T. A 1.8-Mbp fragment on chromosome 1 affects sympathetic response to stress: evaluation in reciprocal congenic strains between stroke-prone spontaneously hypertensive rat and Wistar-Kyoto rat. J Hypertension 2011; 29: 257-265.

33 Hubner N, Wallace CA, Zimdahl H, Petretto E, Schulz H, Maciver F, Mueller M, Hummel O, Monti J, Zidek V, Musilova A, Kren V, Causton H, Game L, Born G, Schmidt S, Müller A, Cook SA, Kurtz TW, Whittaker J, Pravenec M, Aitman TJ. Integrated transcriptional profiling and linkage analysis for identification of genes underlying disease. Nat Genet 2005; 37: 243-253.

34 Nabika T, Cui ZH, Masuda J. The stroke-prone spontaneously hypertensive rat: How good is it as a model for cerebrovascular diseases? Cell Mol Neurobiol 2004; 24: 639-646.

35 Rubattu S, Volpe M, Kreutz R, Ganten U, Ganten D, Lindpaintner K. Chromosoma mapping of quantitative trait loci contributing to stroke in a rat model of complex human disease. Nat Genet 1996; 13: 429-434.

36 Rubattu S, Nubner N, Ganten U, Evangelista A, Stanzione R, Di Angelantonio E, Plehm R, Langanki R, Gianazza E, Sinori L, D’Amati G, Volpe M. Reciprocal congenic lines for a major stroke QTL on rat chromosome 1. Physiol Genomics 2006; 27: 108-113.

37 Jeff B, Clark JS, Anderson NH, Gratton J, Brosnan MJ, Gauguier D, Reid JL, Macrae IM, Dominiczak AF. Sensitivity to cerebral ischaemic insult in a rat model of stroke is determined by a single genetic locus. Nat Genet 1997; 16: 364-367.

38 Rubattu S, Giliberti R, Ganten U, Volpe M. Differential brain atrial natriuretic peptide expression co-segregates with occurrence of early stroke in the strokeprone phenotype of the spontaneously hypertensive rat. J Hypertens 1999; 17: 1849-1852

39 Aitman TJ, Glazier AM, Wallace CA, Cooper LD, Norsworthy PJ, Wahid FN, AI-Majali KM, Trembling P, Mann CJ, Shoulders CC, Graf D, St Lezin EM, Kurtz TW, Kren V, Pravenec M, Ibrahimi A, Abumrad NA, Stanton LW, Scott J. Identification of Cd36 (Fat) as an insulin-resistance gene causing defective fatty acid and glucose metabolism in hypertensive rats. Nat Genet 1999; 21: 76-83.

40 Pravenec M, Landa V, Zidek V, Musilova A, Kren V, Kazdova L, Aitman TJ, Glazier AM, Ibrahimi A, Abumrad N, Qi N, Wang JM, St Lezin E, Kurtz TW. Transgenic rescue of defective Cd36 ameliorates insulin resistance and circulating fatty acid levels in spontaneously hypertensive rats. Nat Genet 2001; 27: 156-158.

41 Pravenec M, Churchill PC, Churchill MC, Viklicky O, Kazdova L, Aitman TJ, Petretto E, Hubner N, Wallace CA, Zimdahl H, Zidek V, Landa V, Dunbar J, Bidani A, Griffin K, Qi N, Maxova M, Kren V, Mlejnek P, Wang J, Kurtz TW. Identification of renal Cd36 as a determinant of blood pressure and risk for hypertension. Nat Genet 2008; 40: 952-954. 
42 Pravenec M, Kurtz TW. Molecular genetics of experimental hypertension and the metabolic syndrome: Frome gene pathways to new therapies. Hypertension 2007; 49: 941-952.

43 Gotoda T, lizuka Y, Kato N, Osuga J, Bihoreau MT, Murakami T, Yamori Y, Shimano H, Ishibashi S, Yamada N. Absence of Cd36 mutation in the original spontaneously hypertensive rats with insulin resistance. Nat Genet 1999; 22: 226-228.

44 Pravenec M, Zidek V, Simakova M, Kren V, Krenova D, Horky K, Jachymova M, Mikova B, Kazdova L, Aitman TJ, Churchill PC, Webb RC, Hingarh NH, Yang Y, Wang JM, Lezin EM, Kurtz TW. Genetics of Cd36 and the clustering of multiple cardiovascular risk factors in spontaneous hypertension. J Clin Invest 1999; 103: 1651-1657.

45 Okamoto K, Aoki K. Development of a strain of spontaneously hypertensive rats. Jp.n Circ J 1963; 28: 282-293.

46 Deng AY. Functional genomics of blood pressure determination: Dissecting and assembling a polygenic trait by experimental genetics. Curr Hypertens Rev 2005; 1 : 35-50.

47 Mashimo T, Voigt B, Kuramoto T, Serikawa T. Rat phenome project: the untapped potential of existing rat strains. J Appl Physiol 2005; 98: 371-379.
48 Goldstein DB. Common genetic variation and human traits. N Eng/ J Med 2009; 360: 1696-1698.

49 Kurtz TW. Genome-wide association 1025. studies will unlock the genetic basis of hypertension: Con side of the argument. Hypertension 2010; 56: 1021-1025.

50 Heinig M, Petretto E, Wallace C, Bottolo L, Rotival M, Lu H, Li Y, Sarwar R, Langley SR, Bauerfeind A, Hummel O, Lee YA, Paskas S, Rintisch C, Saar K, Cooper J, Buchan R, Gray EE, Cyster JG, Erdmann J, Hengstenberg C, Maouche S, Ouwehand WH, Rice CM, Samani NJ, Schunkert H, Goodall AH, Schulz H, Roider HG, Vingron M, Blankenberg S, Münzel T, Zeller T, Szymczak S, Ziegler A, Tiret L, Smyth DJ, Pravenec M, Aitman TJ, Cambien F, Clayton D, Todd JA, Hubner N, Cook SA. A trans-acting locus regulates an anti-viral expression network and type 1 diabetes risk. Nature 2010; 467: 460-464.

51 Morrissey C, Grieve IC, Heinig M, Atamur S, Petretto E, Pravenec M, Hubner N, Aitman TJ. Integrated genomic approaches to identification of candidate genes underlying metabolic and cardiovascular phenotypes in the spontaneously hypertensive rat. Physiol Genomic 2011; 43: 1207-1218.

52 Tanase H, Suzuki Y, Ooshima A, Yamori Y, Okamoto K. Genetic analysis of blood pressure in spontaneously hypertensive rats. Jpn Circ J 1970; 34: 1197-1212. 